\title{
Analysis of the Relationship Between Corporate Governance Mechanisms and Performance of A Firm: A Study on Pakistan's Chemical Industry
}

\author{
Abid Rasheed* \\ Abid.rasheed@ucp.edu.pk \\ Business School \\ University of Central Punjab, Pakistan \\ Ahmed Arman, Ch.Abdullah Imran Sahi \\ Lecturer, University of Lahore \\ Pakistan \\ Ghulam Mustafa, Bilal Sarwar \\ Business School, University of Central Punjab, \\ Pakistan
}

\begin{abstract}
Corporate governance is one of the major topics under discussion from the last two decades. The knowledge is increasing with every passing day as new scandal keeps appearing in the financial world and so are the weaknesses in the CG mechanisms. This study aims to find a relationship between two major elements of CG mechanisms including (board size \& composition and audit committee) and firm performance (ROE and profit margin). The sample size consists of 33 chemical companies listed on the Karachi stock exchange from 2005 to 2015 . The results show a positive relationship between the variables tested in the study. The results also confirm that the theoretical notion of firms with good financial results and performance are those with better corporate governance practices.
\end{abstract}

Keywords: corporate governance, agency cost, firm performance, ROE, profit margin \section{Introduction}

The necessity for corporate governance arises due to the segregation of management from ownership in the modern corporation. The 'principal-agent' issues arise in the course of management activities for which shareholders can have serious concerns. These agency issues can only be negotiated by applying practices of good corporate governance. CG describes the relationship between so many shareholders like management, BoD, shareholders ( majority and minority), and stakeholders. Publication of the SECP CG Code 2017 for publicly listed companies has really facilitated the research area in this corporate sector.

CG mechanisms definitions are varied and far fetched. Some described them as economic and legal institutions (Shliefer and Vishny ,1997), while other describes them as rules and regulations that are altered through the legal and political procedures. Regardless of the definitions, there have been always a need for the change and to reform the CG mechanism. Reforms have been continual and seen across the globe. As the paradigms have shifted from the pure agency bases management and shareholders primacy theories towards more stakeholder and society based approaches such as the Stewardship and stakeholders theory, the reforms somehow followed. Corporate performance is an important aspect

The current issue and full text archive of this journal is available at http://jraspublications.org/index.php/JRAS/issue/archive Journal of Research in Administrative Sciences (JRAS)

IX(I), 22-25, ISSN: 2664-2433 that actually describes a concept that how well an organization utilizes its resources available in either form to achieve the ultimate objective of the organization( the maximization of shareholders wealth) which puts the organization in business and creates a greater prospect for future potential opportunities. Better CG means better utilising of company resources which include the capital.CG , hence helps in generating the inflow of 1 capital in any economy. For the developing countries the capital is relatively harder to get for their economic development. Poor legal and judicial systems are some of the reasons to blame. Another reason is not to comply with the international CG approaches.. There are two important international bodies involved in the development and reforms of the CG mechanism across the borders. One is the International Corporate Governance Network (ICGN) and the other is Organisation for Economic corporations and development (OECD).

The OECD explained in their report that proper mechanism of corporate governance lead firms to confidence of local and international investors. Specifically in case of international investors who give high weightage to those firms which provide fair and transparent disclosures. In Pakistan SECP has also developed code of governance in early 2017 to bridge gap between investors and 
management of a company. Numerous recommendations are included in the code to meet international standards. The major area covered in the codes are about the reforms relating to the directors to make them accountable for their actions. The other key element has been the effectiveness of the audit function in the listed companies..

The main concern of this study is to analyze the relationship between corporate performance and corporate governance for publicly listed chemical companies in Pakistan. In Pakistan corporate governance is characterized, in contrast to developed markets by being more dependent on the large shareholdings by the wealthy and politically influential investors. To attract investments from local smaller investors and foreign institutional investors, CG has to be improved. The contribution made by this study to the literature about the functions of corporate governance in increasing the performance and governance of chemical firms listed in. Since corporate governance contributes a vital role to provide distinguishing feature and helping a company in getting competitive advantage, hence their effect is tested. Secondly, study is purely empirical-based and data is collected particularly from manufacturing-based industry and can be generalized over other via results of these findings. Thus the views of Lane et al. (2006) are also challenged in which it is criticized that corporate governance can create the organizational value of new knowledge.

\section{Literature Review}

Corporate Governance is being defined in various ways. The variations in the definitions are due to the academic backgrounds and perspectives.NonethelessLa Porta, et al. (2000) explained that purpose of corporate governance is to protect investors from possible manipulation caused by insiders due to sensitive information they have. Mostly in any company, these insiders include Board of Directors and those shareholders who have access to information which other do not have. Oman (2001) gave the view that corporate governance are set of laws that regulate relationship between management and investors of a company. Other writers like Cochran and Warwick (1988) explained that corporate governance are rules through which conflicts among different stakeholders of a company can be resolved. These stakeholder's may include top management, shareholders, and creditors This setup saves the corporations from misuse of the powers and encourages better decision making by the BoD. (CIPE, 2002). The term CG can be aapplied to both private and public instiutes; however, in the scope of this study, only the private organisations are concerned. The Corporate governance institutes may include both of them, again, in the context of Pakistan it is only public institutions. And Pakistan CG mechanisms include the company law, Securites and Exhchange Commission of Pakistan (SECP) laws and codes, the guidelines from state bank of Pakistan and the recommendations provided by the Institute of Chartered Accountants of Pakistan (ICAP).Researchers in other countries have thus defined CG as "Corporate laws, securities regulations and the county related ethics" (Omran ,2004). Board Size:

This issue has attracted varying views. Some are in favor of a large board while finding it not relevant larger board attracts a bigger pool of knowlwege and experience while is vital in shareholder wealthe maximastioan (Pfeffer 1972). While others specify the small board size as more effective because of the quality of opinion and control because large contradictions in thinking are avoided among directors. According to Lipton and Lorsch (1992) that for top management it is easy to manipulate the company's performance through large board size. Moreover, for large board size, it is difficult to challenge those policies which are not in favor of shareholders. Different reports suggested that small board size can enhance the implementation of corporate governance rules in the best interest of shareholders. These reports include the Hampel Report (1998), the Malaysian Code on Corporate Governance (2000, Revised 2007), and Saudi Code of Corporate Governance (2006). Similarly, in many studies, it is revealed that board size and firm performance have significant association. (e.g. Yermack, 1996; Vafeas, 2000; Byard, Lin, and Weintrop, 2006). From the above discussion, it can be said that appropriate board size can enhance the performance of a firm. Therefore we can hypothesize that

H1: Appropriate board size will lead to higher performance (high ROE and Profit Margin) for the firm

Board Composition:

Enhanced independence of a director, according to Young (2003) is intuitively appealing because a director in direct relation with CEO or other top management would find it more difficult to mitigate the excessive salary package, or bring more skepticism necessary for effective control. Some studies find boards of directors dominated by outsiders shows better performances for firms (see Weiback 1988, Resenstein and Wyatt, 1990 Mehran, 1995 and John and Senbet 1998), while Weir and Laing (2001) and Pinteris (2002) relates accounting profit or firm value in not such relationship. Also, Forsberg (1989) find no relationship between various performance measures. And the proportion of outside directors. Studies using financial statement data and Tobin's $Q$ find no link between firm performance and independence of board while others who used stock returns data finds a positive relationship. I Based on the fact presented above, appropriate selection and composition of board will lead to high performance for the firm hence we hypothesis the followings

$\mathrm{H} 2$ : Appropriate board composition will lead to higher performance (high ROE and Profit Margin) for the firm

Audit Committee:

The formation of an audit committee is becoming the requirement for many companies listed in stock market. Members of an Audit Committee are selected from the Board of Directors who are responsible for proper implementation of internal control procedures and to make sure true and fair financial reporting and disclosures. These audit committees are basically formed to have enough knowledge necessary to perform their responsibilities in a competitive manner.

Klein (2002) found that earnings management and independent audit committee had a negative relationship. Anderson, Mansi and Reeb (2004) concluded that lower debt financing costs there must be an independent audit committee. Based on these findings we create third hypothesis for our review in this study;

H3: Presence of audit committee will lead to higher performance (high ROE and Profit Margin) for the firm.

\section{Research Methodology}

\section{Research Framework}

The study tries to examine the linkage/relationship between corporate governance and performance of the organization of chemical industry firms. The proposed hypothesis and research framework developed is depicted below;

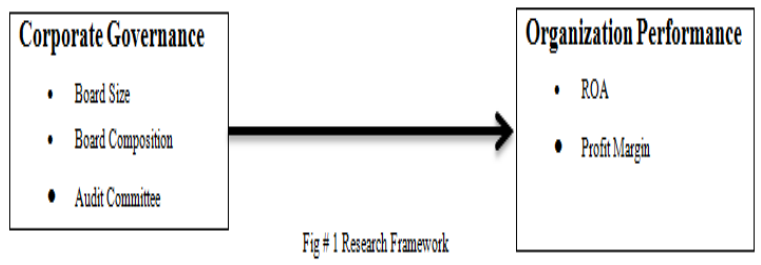

\section{Sampling and Measurement}

There are thousands of small and big chemical factories, trading firms and manufacturing units. The overall population of the chemicals industry in Pakistan includes local \& foreign development and industrial firms/units. Their network is segregated across the country. Due to the resources and time constraints, it was not possible to cover the country. So for fulfilling the requirement of this study we have selected only 33 units/chemical companies which are listed on Karachi Stock exchange. These units are working under different capacities including manufacturing of enduser products or preparation of buyer to buy product. They are also involved in the import and export of these products as well.

Out of the total population of more than 100 (SMEDA) chemical firms at present in the country, a total sample of 33 firms were 
selected. The sample includes representation from all the brands and it was assured that the firm was listed in KSE from at least five years ago. The data was collected from different secondary sources including websites of Securities and Exchange Commission of Pakistan (SECP), Small and Medium Enterprise Development Authority (SMEDA), State Bank of Pakistan (SBP), Karachi Stock Exchange (KSE), different reports, business newspapers and other related materials of past research.

\section{Independent Variable}

\section{Corporate Governance}

To measure the governance of firm, evaluating mechanism is used to examine the rigor of a set of governance practices that covers various governance categories: such as board composition \& size, and audit committee.

\section{Dependent Variables}

In this study, three measures of performance are used which are Tobin Q, Return on Equity (ROE), and Profit Margin (PM). Tobin $\mathrm{Q}$ is the ratio of the market value of capital employed (equity and debt) and the cost of all assets. ROE is calculated as net profit as percentage of shareholder's equity. PM is percentage of net profit with respect to sales.

\section{Control Variables}

The firm size plays an effective and impact able role by increasing the firm's ability and methodology to tackle issues better. The increased number of employees and high technology and IT equipment availability also enhances their ability to induce better practices. Also working in a number of years increases the capacity to work in a team environment. The variable can impact on the dependent variables in positive ways. Therefore, within the scope of this study subject variable is held constant. To account for demographic and socioeconomic factors (Kim, Aldrich, \& Keister, 2006), we included controls for Firm size was included and for the fact that larger ventures may have better chances of survival (Wennberg, Delmar\& McKelvie ,2016). Guided by existing research, other control variables theorized to influence corporate governance we used demographic factors and socioeconomic (Kim, Aldrich, \& Keister, 2006), we considered controls for; education, measured as the total years of schooling; promotion, measured as the number of years since promoted.

\section{Results}

In this study impact of corporate governace on performance of a firm is analysed. Three measures are uased to calculate firm performance which are Tobin Q, ROE, and PM. Results of the study had confirmed that corporate governance practices significantly impact performance of a firm. As previous studies had also shown same findings for developed and developing markets (La Porta, et al. 2002; Drobetz, et al. 2004).. So similar situation is also exist in Pakistan.

In this study 33 listed firms were selected from Chemical Industry of Pakistan. For these 33 firms average board size were 9 out of which 7 directors were from outside of a firm. In $86 \%$ of companies post of Chief Executive and Board Chairman were not hold by a single person but in remaining companies these two posts are hold by a same person.

\begin{tabular}{|l|c|c|c|c|c|}
\hline \multicolumn{7}{|c|}{ Table 1: Descriptive Statistics } \\
\hline & ROE & $\begin{array}{c}\text { Profit } \\
\text { Margin }\end{array}$ & $\begin{array}{c}\text { Board } \\
\text { Size }\end{array}$ & $\begin{array}{c}\text { Board } \\
\text { Composition }\end{array}$ & $\begin{array}{c}\text { Audit } \\
\text { Committee }\end{array}$ \\
\hline Mean & 0.9029 & 0.6324 & 9.244 & 6.874 & 0.825 \\
\hline Median & 0.475 & 0.0 .50 & 9 & 7 & 0.83 \\
\hline Mode & 0.1 & 0.02 & 9 & 7 & 0.8344 \\
\hline Std. Dev. & 1.5703 & 0.1837 & 2.37 & 2.315 & 0.01175 \\
\hline Skewness & 2.378 & -5.601 & 0.471 & 0.423 & -0.411 \\
\hline Kurtosis & 8.164 & 42.457 & -0.368 & -0.496 & -0.125 \\
\hline Range & 11.35 & 1.94 & 11 & 9 & 0.5 \\
\hline Min & -1.98 & -1.56 & 5 & 3 & 0.5 \\
\hline Max & 9.37 & 0.38 & 16 & 12 & 1 \\
\hline Sum & 126.4 & 3.55 & 1296 & 954 & 121 \\
\hline
\end{tabular}

Table \# 2 Correlation Matrix

\begin{tabular}{|c|l|c|c|c|c|c|c|c|c|c|c|}
\hline $\begin{array}{c}\text { Sr. } \\
\#\end{array}$ & Variables & Mean & $\begin{array}{c}\text { Standard } \\
\text { Deviation }\end{array}$ & $\mathbf{1}$ & $\mathbf{2}$ & $\mathbf{3}$ & $\mathbf{4}$ & $\mathbf{5}$ & $\mathbf{6}$ & $\mathbf{7}$ & $\mathbf{8}$ \\
\hline $\mathbf{1}$ & Firm Size & 1.26 & .441 & 1 & & & & & & & \\
\hline $\mathbf{2}$ & Demographics & 1.51 & .501 & $.323^{* *}$ & 1 & & & & & & \\
\hline $\mathbf{3}$ & Qualification & 2.60 & .573 & .078 & .067 & 1 & & & & & \\
\hline $\mathbf{4}$ & Board Size & 2.19 & .821 & -.060 & $-.204^{* *}$ & $.205^{* *}$ & 1 & & & & \\
\hline $\mathbf{5}$ & Board Comp. & 1.64 & .904 & $-.244^{* *}$ & $-.473^{* *}$ & $-.150^{*}$ & $.216^{* *}$ & 1 & & & \\
\hline $\mathbf{6}$ & Audit Commit & 2.91 & .610 & $.161^{*}$ & .043 & .129 & -.003 & $.121^{* *}$ & 1 & & \\
\hline $\mathbf{7}$ & ROE & 2.85 & .899 & .130 & .004 & .134 & $.010^{* *}$ & $.014^{* *}$ & $.241^{* *}$ & 1 & \\
\hline $\mathbf{8}$ & Profit Margin & 3.56 & .945 & -.098 & -.106 & .094 & .123 & .127 & $.389^{* *}$ & $.116^{*}$ & 1 \\
\hline
\end{tabular}

**. Correlation is significant at the 0.01 level (2-tailed).

*. Correlation is significant at the 0.05 level (2-tailed).

In the above Table 2, we can see that significant positive correlation exist among ROE and all measures of corporate governance except for audit committee where negative and insignificant correlation exist. Same relationship is found among PM and corporate governance where again onlu audit committee found to have insignificant relationship with performance of a firm (PM).

\section{Discussion and Conclusion}

Corporate governance is a mechanism to ensure that the wealth of the investors is safe. Safer investments will be matched with a lesser rate of return. This concludes that that capital will be attracted by the low-risk countries, even they offer less return. Investors might seek to take the risk for an increased return on their capital, however, they will do it rationally. Poor CG practices lead the way for the flight of the capital, All enterprises suffer the consequences in that country regardless of how steady a particular company's practices may be. Hence the stronger CG practices are required by the investors to provide capital.

Results of our study had shown that board composition had significant relationship with board composition. In our case representation of independent and outside directors in the board was 7 out of 9 on average which confirm that indepdency of board is helpful to counter malafide practices which in long term is translated into imrove performance. These findings are similar to results found 
by Forsberg (1989), Weisbach (1991), Bhagat and Black (2002),Klapper and Love (2004), and Sanda et al (2011).

Findings of this study are helpful for authorities and management of companies. SECP and Pakistan Stock Exchange can make sure proper implementation of corporate governance rules in companies listed. Through proper implementation management of a company may be refrain from manipulating of information and can work in the best interest of sharegolders. Similarly shareholders may force top management of a company to follow corporate governance rules in order to safeguard their interest.

\section{Limitations of the Study}

Some of the notable limitations of the study conducted are given below;

- Since the research was conducted using secondary data tool, the figures and values provided the data are considered to have chances of error and omissions. It might be possible that the person may be biased in answering in some manner as they may be close to reporting authority.

- The overall population of the research was very large and represent less than $10 \%$ of the total number of the firm in Pakistan. Therefore the results of the study cannot be generalized over the wide range of industries.

- The research is conducted in the chemical sector of the country. It might be possible that results may differ in the other sectors of the country. Also, the sample size of the study is not very large.

\section{Future Scope}

Based on the study conducted above, researchers and scholars can extend the paradigm of this area in the future on the followings;

- The work can be carried out on the other sector of the industry, including education, manufacturing, hospitals, and others. Also, instead of a panel, the cross-sectional and longitudinal methodology can be adopted in order to support further empirical evidence on this topic and variables.

- Both variables have a high depth of literature, and much work is done on the topics. However, they are still not tested together before this study. In the future, distant relationships can be checked by applying a variety of theories and knowledge backing these variables in the literature that will further improve the existing body of knowledge for industry and well academic researchers.

\section{References}

i. Anderson, R. C., \& Reeb, D. M. (2004). Board composition: Balancing family influence in S\&P 500 firms. Administrative science quarterly, 49(2), 209-237.

ii. Bashir, U., Fatima, U., Sohail, S., Rasul, F., \& Mehboob, R. (2018). Internal Corporate Governance and Financial Performance Nexus; a Case of Banks of Pakistan. Journal of Finance and Accounting, 6(1), 11-17.

iii. Berle, A. A., \& Means, G. G. C. (1991). The modern corporation and private property. Transaction publishers.

iv. Bhagat, S., \& Black, B. (2001). The non-correlation between board independence and long-term firm performance. J. CorP. 1., 27, 231.

v. Bishop, B. (2002). Investment and corporate governance in East Asia. CIPE Feature Service.

vi. Calder, A. (2008). Corporate governance: A practical guide to the legal frameworks and international codes of practice. Kogan Page Publishers.

vii. Drobetz, W., Schillhofer, A., \& Zimmermann, H. (2004). Corporate governance and expected stock returns: Evidence from Germany. European financial management, 10(2), 267293.

viii. Fama, E. F., \& Jensen, M. C. (1983). Separation of ownership and control. The journal of law and Economics, 26(2), 301-325.

ix. Fama, E. F., \& Jensen, M. C. (1983). Separation of ownership and control. The journal of law and Economics, 26(2), 301-325. x. Hermalin, B. E., \& Weisbach, M. S. (1991). The effects of board composition and direct incentives on firm performance. Financial management, 101-112.

xi. Iu, J., \& Batten, J. (2001). The implementation of OECD corporate governance principles in post-crisis Asia. Journal of Corporate Citizenship, (4), 47-62.

xii. Jensen, M. C., \& Meckling, W. H. (1979). Theory of the firm: Managerial behavior, agency costs, and ownership structure. In Economics social institutions (pp. 163-231). Springer, Dordrecht.

xiii. Kim, P. H., Aldrich, H. E., \& Keister, L. A. (2006). Access (not) denied: The impact of financial, human, and cultural capital on entrepreneurial entryin the United States. Small business economics, 27(1), 5-22.

xiv. Kirkpatrick, G. (2009). The corporate governance lessons from the financial crisis. OECD Journal: Financial Market Trends, 2009(1), 61-87.

xv. Klein, A. (2002). Audit committee, board of director characteristics, and earnings management. Journal of accounting and economics, 33(3), 375-400.

xvi. La Porta, R., Lopez-de-Silanes, F., \& Shleifer, A. (1999). Corporate ownership around the world. The journal of finance, 54(2), 471-517.

xvii. Mallin, C. A. (Ed.). (2011). Handbook on international corporate governance: country analyses. Edward Elgar Publishing.

xviii. Sanda, A. U. (2011). Board independence and firm financial performance: Evidence from Nigeria. Klapper, L., Laeven, L., \& Love, I. (2006). Corporate governance provisions and firm ownership: Firm-level evidence from Eastern Europe. Journal of International Money and Finance, 25(3), 429-444.

xix. Shleifer, A., \& Vishny, R. W. (1997). A survey of corporate governance. The journal of finance, 52(2), 737-783.

xx. Ullah, A. (2018). The Impact of Corporate Governance on Voluntary Disclosure: Evidence from Pakistan. City University Research Journal, 8(2).

xxi. Wennberg, K., Delmar, F., \& McKelvie, A. (2016). Variable risk preferences in new firm growth and survival. Journal of Business Venturing, 31(4), 408-427.

xxii. Yermack, D. (1996). Higher market valuation of companies with a small board of directors. Journal of financial economics, 40(2), 185-211. 